\title{
Remittances, Foreign Direct Investment and Economic Growth in North Africa Region Evidence from Panel ARDL Model
}

\author{
Ouamer Mohammed
}

University of M'sila

\begin{abstract}
This paper aims to measure the impact of remittances (REMT) and foreign direct investment (FDI) on the economic growth in North Africa region. It used balanced Panel data over the period of 2000-2018 to estimate the impact of both REMT inflows as percent of gross domestic product (GDP) and FDI inflows as percent of GDP on the growth rate of GDP per capita in Algeria, Egypt, Morocco, and Tunisia. Both Wald and Hausman tests indicated that Random Effect Model approach (REM) is the appropriate static model for the data compared to both the Pooled Regression Model (PRM) and the Fixed Effect Model (FEM) approaches. Levin, Lin \& Chu and Im, Pesaran \& Shin panel unit root tests denoted that all variables are stationary at the first differences (I (1)). Kao and Pedroni Panel co-integration tests confirmed existing a long-run dynamic relationship between REMT, FDI and GDP per capita. Pooled Mean Group (PMG) approach was used to estimate a panel ARDL model. The main finding is that external sources of capital inflows such as remittances inflows and foreign direct investment has a different impact on the economic growth in North Africa countries, while REMT has a statistically significant positive impact, FDI has a statistically insignificant positive impact on GDP per capita in the end. The estimation of short-run model indicated that Error Correction Term (ECT) has a significant negative coefficient consistent with the theory; and its high value indicates the speed of returning to the long-term balance between the model variables.
\end{abstract}

Keywords: balanced Panel data; co-integration; GDP per capita; panel ARDL. Unit root tests 